\title{
Twee versoenbare konstrukte in resente historiese Jesus-navorsing, Deel II: Andries van Aarde ${ }^{1}$
}

\author{
D J C van Wyk (jr) \& Andries van Aarde \\ Departement Nuwe-Testamentiese Wetenskap \\ Universiteit van Pretoria
}

\begin{abstract}
Two compatible constructs in current historical Jesus research, Part II: Andries van Aarde

In Part I, John Dominic Crossan's profile of the historical Jesus was discussed. This article focuses on Andries van Aarde's view. According to Van Aarde, Joseph the father of Jesus should historically be seen as a legendary figure and that Jesus grew up fatherless. The stories of Jesus' virginal conception are myths. However, they reflected an historical context of the separation between the postEaster synogogical movement and the Jesus movement. The article also discusses Van Aarde's view on the resurrection narratives, the contininuity and discontininuity between Jesus, and earliest Christianity and his view on canon and dogma. It concludes with a comparison between Corssan's and Van Aarde's perspectives.
\end{abstract}

\section{INLEIDING}

Jare se navorsing op talle terreine van die Nuwe-Testamentiese wetenskap in die algemeen en op die gebied van die historiese Jesus-navorsing in die besonder, het vir Andries van Aarde [2001] uitgeloop op sy Jesus-boek, getiteld Fatherless in Galilee: Jesus Child of God. Die boek het 'n duidelike eksistensiële stempel van 'n gelowige navorser wat

\footnotetext{
1 Hierdie artikel is gebaseer op ' $n$ gedeelte uit die DD-proefskrif van D J C van Wyk (jr), getitel "Die relevansie van historiese Jesus-navorsing vir kerk en teologie: 'n Hermeneutiese vraagstelling". Die proefskrif is voorberei onder promotorskap van prof dr A G van Aarde, Fakulteit Teologie, Universiteit van Pretoria (2000).
} 
voluit erns maak met die wetenskaplike, historiese omgaan met die geskrifte van die vroeë Christendom. In die boek beskryf Van Aarde iets van sy eie reis op die lewenspad en toon hy aan hoe sy ervaring van die reis van Jesus sy eie lewe en sy verstaan van Jesus beinvloed het.

\subsection{Persoonlike betrokkenheid by Jesus-navorsing}

Van Aarde ([2001]:6-7) wil, op voetspoor van Albert Schweitzer, rekening hou daarmee dat navorsers (en nie-eksegetiese gelowiges) se profiele van Jesus sterk verband hou met daardie persoon se eie lewe, persoonlikheid en omstandighede. Navorsing vanuit die godsdienspsigologie dui daarop dat daar 'n duidelike verband bestaan tussen die beeld wat mense van God het en die beeld wat hulle van hulle ouers het. Insgelyks is daar 'n duidelike verband tussen hoe Christengelowiges se konsep van Jesus en hoe hulle hulle konsep van hulleself vorm en ontwikkel. "There is no doubt, profiles of Jesus are constructed according to someone's own likeness" (Van Aarde [2001]:7). Dit hoef derhalwe nie as 'n swakheid beskou te word wanneer hyself erken dat sy eie lewe en agtergrond 'n beduidende rol in sy konstruk van die historiese Jesus speel nie. Daar sal nietemin altyd beperkings (constaints) wees. 'n Bepaalde beeld van Jesus kan óf 'n vervreemding óf 'n verdieping van die saak wees waarvoor Jesus gestaan het. Daar is met ander woorde perke aan persoonlike vormgewing van 'n bepaalde Jesus-beeld.

Teen hierdie agtergrond is dit belangrik om te let op die invloed wat ingespeel het op Van Aarde se lewe en wat meegewerk het om sy beeld van die historiese Jesus te vorm. Van Aarde ([2001]:10) het oor jare op 'n baie besondere manier by Jesus-navorsing betrokke geraak. Om Jesus te ken, was van kleins af vir hom ' $n$ besondere ervaring. Self het hy nie in 'n goeie verhouding met sy eie vader geleef nie. Daarteenoor het hy as kind en as volwassene die warmte en geborgenheid van die geloofgemeenskap ervaar. Van Aarde se eie ervaring van vaderloosheid het vir hom, in 'n sekere sin, die onderwerp van die vaderloosheid van Jesus aktueel gemaak en hom gedryf tot die Jesus-studies waarmee hy besig is. Daarmee kwalifiseer hy wel dat hy nie sy navorsing begin het met die tema van vaderloosheid in sy gedagtes nie, maar dat sy navorsing hom eventueel daarvan oortuig het dat Jesus as 'n vaderlose seun opgegroei het. Hierdie bevinding het hom wel eksistensieel aangegryp op grond van sy eie lewensomstandighede en ervarings. 


\subsection{Van Aarde se Jesus}

'n Onderskeidende kenmerk van die navorsing van Van Aarde ([2001]:11, 112), is dat hy van mening is dat daar op 'n spesifieke terrein histories méér oor die lewe van Jesus gesê kan word as wat tot dusver die geval was. In die verlede het historiese Jesus-navorsing gefokus op die lewe van Jesus nadat Hy by Johannes die Doper betrokke geraak het. Daar is algemeen aanvaar dat die geboorteverhale te veel legendariese stof bevat om daadwerklik iets histories daarvan te maak. In dié verband wil Van Aarde 'n nuwe bydrae lewer. Daar kan volgens hom wel historiese uitsprake oor die lewe van Jesus vóórdat sy paaie met die van Johannes die Doper gekruis het, gemaak word (Van Aarde [2001]:143).

\subsubsection{Jesus se lewe vóór Johannes die Doper: Josef - 'n legendariese vader}

Alhoewel byna al die verhale oor die geboorte en daaropvolgende gebeure onhistories is (Van Aarde [2001]:143), staan een ding vas: Jesus was vaderloos. Die Josef-figuur is opmerklik afwesig tydens die openbare optrede van Jesus (terwyl sy moeder en res van die familie telkens gespesifiseer word - vgl Mark 3:31-34). Die figuur van Josef kom glad nie in die vroeë bronne agter Matteus en Lukas voor nie. Daar is geen vermelding van Josef in Paulus se briewe nie, ook nie in Markus, Q of die Evangelie van Tomas nie. Josef speel ook geen rol in die dokumente wat op Paulus bou nie. Dit is duidelik dat die Josef-figuur die eerste keer voorkom in daardie dokumente waarin die Jesus-beweging die eerste keer te doen gekry het met onvleiende konfrontasies oor waar Jesus vandaan gekom het. "In the Christian tradition the role of Joseph is part and parcel of either the polemics against Jesus' alleged scandalous birth or the underpinning of Mary's (perpetual) virginity and Jesus' two 'natures' being God and human" (Van Aarde [2001]:128). Verwysings na Josef as die vader van Jesus moet dus veel eerder gesien word as "konfessionele kommentaar" op onder andere die beledigende berigte oor Jesus se herkoms en oor Jesus se (histories) barmhartige houding teenoor vrouens en kinders (Van Aarde [2001]:129).

Die gebrek aan onafhanklike, meervoudige betuiging rakende die Josef-figuur dui waarskynlik daarop dat Jesus vaderloos grootgeword het (Van Aarde [2001]:128). Josef moet teen dié agtergrond waarskynlik beskou word as 'n legendariese figuur. In die 
wysheidsliteratuur van die Ou Testament word die Josef-figuur aangetref. Hy is die weggooikind wat 'n Israelitiese wysheidsleraar in Egipte geword het. Josef word in die Ou Testament as 'n Moses-prototipe voorgestel wat tot Israel se redding kom in 'n tyd van nood (Van Aarde [2001]:36). Uit tradisies van die Pentateug (Deut 33:13-17; Gen 37:1-11) blyk dit dat Josef, en nie Juda nie, gesien is as die legitieme opvolger van hulle vader Jakob. Binne die Jakob-tradisie is Betel gesien as die heilige plek waar hemel en aarde ontmoet het, en God met Jakob (en sy nageslag) 'n verbond gesluit het. Met die sentralisasie van die kultus in Jerusalem is reeds gepoog om van die Betel-tradisie as fokuspunt ontslae te raak (kyk Hos 1:4-5). Met die ballingskap is die tradisie egter finaal die nekslag toegedien toe mense uit die Noordryk gebrandmerk is as buitestaanders en later ontwikkel het in die Samaritane (Van Aarde [2001]:318). Die nageslag van Josef is derhalwe beskou as die voorvaders van die Samaritane (Van Aarde [2001]:319ev). Die Samaritane is in die tyd van Jesus deur die Judeërs (Judeans) gemarginaliseer as onwettige kinders van Israel. Die Josef-figuur was vir die Griekssprekende Israeliete 'n etiese paradigma. Vir die Judeërs was hy egter die teënstander van Juda en die Judeërs. Die Josef-mense is deur die Judeërs as basters beskou.

Deur Goddelike ingrype word Josef (die seun van Jakob, volgens Matt 1:16) egter in die Nuwe Testament die redder van Maria en haar kind. So word die Noorde (Israel) en die Suide (Juda) weer bymekaargebring en kry Jesus se inklusiewe houding teenoor die Samaritane meer perspektief. Terselfdertyd is die verhale oor die maagdelike verwekking van Jesus apologie teenoor die beskuldiging deur die Fariseërs dat Jesus 'n illegitieme herkoms het. Dit verteenwoordig iets van die Christene se verstaan van Jesus se subversiewe beoordeling van die Jerusalemse tempelideologie (Van Aarde [2001]: 201). Dit alles beteken dat die figuur van Josef as die vader van Jesus niks meer as 'n legende is nie. Die konsekwensie dáárvan is dat die vaderloosheid van Jesus ernstig geneem moet word (Van Aarde [2001]:210).

\subsection{2 'n Mitiese maagdelike verwekking}

Die geboortevertellings in Matteus 1:18-25 en Lukas 2:1-7 moet albei duidelik binne bepaalde kontekste gesien word. Matteus het die intensie gehad om Jesus as 'n tipe Moses-figuur te teken (vgl Allison 1993). Op voetspoor van post-Ou-Testamentiese ver- 
tellings oor die maagdelike verwekking van Moses (kyk Van Aarde [2001]:188) toon Matteus dié en verskillende ander parallelle tussen Jesus en Moses aan (kyk Matt 2:1620; Matt 5:1-7:27). Die geboortevertellings in Lukas moet gesien word teen die agtergrond van die legende van die goddelike geboortes van keisers en ander godeseuns, onder andere die verhaal van Perseus se maagdelike verwekking en die implikasie daarvan as kind van Zeus (Van Aarde [2001]:275-309). Dit is byvoorbeeld interessant om daarop te let dat die tweede-eeuse filosoof Celsus die Christene daarvan beskuldig het dat hulle die legende van Perseus as kind van Zeus oorgeneem het en op hulle verhaal van Jesus toegepas het (Van Aarde [2001]:111ev).

Van Aarde neem ook die mites rondom Herakles in oënskou. Soos in die geval van Perseus, is daar ook by Herakles sprake van 'n goddelike konsepsie. Binne die konsep van Herakles se aanneming as kind van Zeus (wat sy vergoddeliking impliseer) vertel Seneca van 'n "leë graf" en Herakles se hemelvaart. Jesus se volgelinge het Hom "Seun van God" genoem (vgl Rom 1:4). Paulus is bekend vir sy gebruik van die term "aanneming tot kindskap" (Van Aarde [2001]:12; Rom 8:23; Gal 4:5). Hierdie konsep van Paulus moet volgens Van Aarde ([2001]:287ev) gesien word as 'n parallel met onder andere Seneca se vertelling van Herakles en die Romeinse aannemingspraktyk. Soos Paulus, argumenteer ook die evangelis Johannes dat die gelowige in enige mate deel kan hê aan die seunskap van Jesus (vgl Joh 3:16 met 1 Joh 4:7-9).

In die verlede is hierdie mites afgemaak as irrelevant vir die historiese ondersoek na Jesus. Van Aarde ([2001]:114) wil egter aantoon dat die mites die intensie gehad het om Jesus enersyds as ' $n$ tipe Moses-figuur in die Matteusevangelie uit te beeld en andersyds in die Lukasevangelie as polemiek teen die keiserkultus. Dié insigte lei daartoe dat ' $n$ besondere aspek in Jesus se lewe, te wete sy vaderloosheid, uitstaan.

\subsection{3 'n Vaderlose Jesus}

In antieke tye was die "mite van die afwesige vader" 'n bekende en algemene konsep. Die stelling dat Jesus as 'n vaderlose seun opgegroei het, stel Van Aarde ([2001]:14,36) as 'n waarskynlike historiese feit. In eerste-eeuse Galilea het dít verreikende betekenis gehad. In sosiaal-wetenskaplike terme, met die hulp van kruis-kulturele antropologie en sosiale psigologie, kan 'n ideaal-tipiese situasie beskryf word. In terme van só 'n ideaal- 
tipe kan verduidelik word hoe 'n persoon wat die stigma van vaderloosheid het, vir God as sy Vader aanneem en vertrou (kyk Van Aarde [2001]:79, 101). Teen die agtergrond van die Jerusalemse tempelkultus het die vaderloosheid van Jesus verreikende implikasies vir Hom as mens ingehou. Hy was sonder enige vorm van sosiale identiteit. Sonder 'n vader het $\mathrm{Hy}$ nie toegang tot die tempel gehad nie, kon Hy nie 'n kind van Abraham wees nie, en gevolglik ook nie 'n "kind van God" genoem word nie (Van Aarde [2001]:238).

Navorsing (vgl ook Jacobs-Malina, in Van Aarde [2001]:228) het getoon dat Jesus, die "vaderlose seun", nie opgetree het volgens die rolverwagting van die oudste seun in 'n patriargale familie nie. Sy optrede kan eerder vergelyk word met dié van 'n vrou. Die hart van Jesus se boodskap was sy siening van hoe God as Vader by mense in nood teenwoordig is (Van Aarde [2001:302). Jesus het die metafoor "koninkryk van God" as 'n beeld gebruik om hierdie boodskap te kommunikeer (vgl oa Matt 6:9-10; Luk 13:18). In dié opsig was Jesus se alternatiewe definisie van die "koninkryk van God" nie 'n konsep in futuristiese apokaliptiese simbole nie. Aan die een kant was die koninkryk van God vir Jesus soos 'n "uitgebreide familie" met God as die "familiehoof" (dws pater familias). Aan die ander kant gaan die koninkryk van God nie eers, in apokaliptieskatastrofale wyse, aan die einde van hierdie-wêreldse bedeling verwerklik nie. God se domein was vir Jesus iets wat reeds teenwoordig was.

Uiteindelik het die vaderloosheid van Jesus ook sy optrede teenoor sy medemens bepaal. Binne ' $n$ ideaal-tipe situasie het ' $n$ weggooikind ' $n$ anti-patriargale temperament ontwikkel wat tot redding van veral vrouens en kinders gekom het (Van Aarde [2001]:11, 95).

Jesus' subjective identity seems to consists in the status he saw himself occupying: the protector and defender of the honor of outcasts, like abandoned woman and children, giving the homeless a fictive home. And finally, Jesus' optative identity, which consists in that status he wished he could occupy but from which he was debarred, seems to be a child of Abraham, child of God that could be the reason why the fatherless Jesus called upon God as his father.

(Van Aarde [2001]:240) 
Jesus se ernstige erbarming oor "vaderlose straatkinders" kom duidelik uit die onafhanklike, meervoudige tekste na vore (ThomEvang 22:1-2; Mark 10:13-16 = Matt 19:13-15 = Luk 18:15-17; Matt 18:13; Joh 3:1-10). Jesus het die kind, en nie die vader nie, model gemaak vir die een wat die koninkryk van God binnegaan. Daardeur het die vaderlose Jesus die hiërargiese uitgangspunte van die totale samelewing van sy tyd onderstebo gekeer.

Terselfdertyd het dit uitgemond in die selfverstaan van die Jesus-beweging as die nuut totstandgekome fiktiewe familie van God (Matt 23:9; Van Aarde [2001]:266). Jesus se eksistensiële belewenis van wat dit beteken om kind van God te wees, het uitgeloop op die belydenis van Christene dat Jesus op 'n metaforiese manier God se seun is (Rom 3:4). Hierdie eksistensiële belewenis van Jesus blyk onder andere uit sy gebruik van die woord "Abba" vir sy hemelse Vader. Alhoewel Paulus nie die woord "Abba" (wat gelowiges vir God in Romeine 8 gebruik) in presies dieselfde sin gebruik nie, is daar nietemin 'n belangrike raakpunt: Kinders van God is nie noodwendig biologiese kinders van Abraham nie.

...[B]y means of the term adoption as child, Paul gives expression to the conviction that believers are not by nature children of God, but on the basis of their being bound to Jesus, the Child of God. The concept of adoption as God's child is a recurrent theme in Greco-Roman and Hellenistic Semitic literature.

(Van Aarde [2001]:276)

Kort en kernagtig kan die volgende beeld van die historiese Jesus, vóór sy bemoeienis met Johannes die Doper, geteken word (Van Aarde [2001]:97): Jesus, die Seun van Maria, was 'n plattelander (peasant) uit die Galilese dorp Nasaret. Hy het vaderloos grootgeword, was waarskynlik 'n skrynwerker van beroep wat jukke en deurrame gemaak het. Hy was ongeletterd in die sin dat Hy nie kon lees of skryf nie. Hy het in konflik met sy familie geleef. 


\subsubsection{Jesus en Johannes die Doper}

Jesus het bewustelik bande met die volgelinge van Johannes die Doper gesoek en dit ook gevind. Later het Hy egter van die Doper wegbeweeg en sy eie groep volgelinge rondom Hom versamel. Die bewustelike breuk met Johannes die Doper kom na vore in die onderskeidende betekenis wat die doop-rite vir die Jerusalem-gemeente gehad het.

The baptism by John the Baptist was a water ritual that initiated a lifestyle to be lived when and where God reigns. The fellows of the Jesus movement in Jerusalem institutionalized a "spiritual babtism" in the name of the Father, and the Son and the Spirit of God as sign of initiation into a discipleship of the "heavenly kingdom".

(Van Aarde [2001]:320)

Jesus het die betekenis van sy doop (deur Johannes) in die lig van onder andere Jesaja 1:16-17 in Galilea gaan uitleef (kontinuïteit), maar Jesus het nie die dooppraktyk gaan voortsit nie (diskontinuïteit). Jesus het presenties inhoud gegee aan Johannes se boodskap van 'n naderende "futuristiese" koninkryk van God (dws kontinuiiteit én diskontinuïteit).

\subsubsection{Die lewe van Jesus}

Jesus se lewe kan gekarakteriseer word deur die absolute vertroue wat Hy in God as sy Vader gehad het. Veral die "nobodies" van die plattelandse Galilea was diegene wat graag na Hom geluister het. Wat die verkondiging van Jesus betref, was dit wat Hy geleer het, in die woorde van Robert Funk, kort, skerp en gemaklik om te onthou. Sy verhale was simbolies van aard, met 'n oop einde en skokkend. Sy dade en optrede was dieselfde en is beskou as metafories in hulleself, toegespits op resosialisering. Beide sy woorde en sy dade was radikaal onkonvensioneel in die sin dat dit die kulturele grense van sy tyd oorskry het.

Die konsep "koninkryk van God", as sentrale element in sy prediking, was nie apokalipties georiënteerd nie, maar wel daarop afgestem om vertroebelde verhoudings te 
heel deur middel van ' $n$ "politics of compassion" en die onbemiddelde teenwoordigheid van God.

\subsubsection{Die dood van Jesus}

Jesus se alternatiewe wysheid het Hom in stryd gebring met die tempelideologie van sy dag. Dit het Hom ook in konflik gebring met die Fariseërs. Hy is deur die Sadduseërs en die priesterlike elite as 'n bedreiging beskou en uiteindelik deur die Romeine soos 'n krimineel gekruisig. Jesus het Homself waarskynlik nie as 'n martelaar gesien nie. Hy was 'n sosiaal-veragte en beslis nie 'n tipe Robin Hood-figuur wat tot die adel behoort het en vanuit ' $n$ posisie van bo tot redding van die armes gekom het nie (Van Aarde [2001]:99).

$\mathrm{Na}$ sy dood is daar nie sorg gedra vir wat met sy liggaam gebeur het nie. Indien Hy begrawe sou gewees het, het dit allermins in ' $n$ respektabele familiegraf plaasgevind. "Jesus of Nazareth died as he was born - a nobody among nobodies." Nadat sy vergruisde liggaam nie behoorlik versorg en begrawe is nie, het Hy in die kerugma opgestaan. Met ander woorde, Hy het voortgeleef in die oorvertel van sy saak (die Jesus$s a a k)$. Hierdie voortleef van Jesus gaan steeds voort wanneer Hy in die kerugma gehonoreer word as die kind van God (Van Aarde [2001]:138).

Verskillende persone in die vroeë kerk het later deur middel van 'n "altered state of conciousness" ervarings van die opgestane Jesus as die "kind van die mensdom" [Child of Humanity] gehad (vgl (inter alia Matt 24:30; 27:52-53; 28:16-20). Petrus, Paulus en van die ander dissiples het hierdie ervarings gehad waarskynlik op grond van 'n skuldgevoel, Maria Magdalena waarskynlik op grond van intense verlange na Jesus (kyk Mark 16:1; Matt 28:1; Luk 24:10; Joh 20:1; Evang van Petrus 12:50; Van Aarde [2001]:138ev).

\subsection{Vanaf Jesus tot by die kerk}

Jesus is in die na-Pase periode deur die verskillende Jesus-bewegings "verchristelik'. Uit die dokumente van die Nuwe Testament is klemtone van hierdie "verchristeliking" aan te toon (Van Aarde [2001]:29). Hierdie verhoging van Jesus deur die kerk kan onder andere 
duidelik gesien word wanneer gelet word op die gebruik van eretitels in die geskrifte van die Nuwe Testament (Van Aarde [2001]:275-309).

Oor die na-Pase ontwikkeling van die Jesus-beweging trek Van Aarde (kyk o a [2001]:320-332) die volgende breë lyne om die oorgang vanaf Jesus tot by die kerk aan te dui:

- Die vroegste Jesus-beweging in Jerusalem het ontstaan op grond van ervarings wat mense van die opstanding van Jesus gehad het. Na die afgryse van die kruisdood is Jesus se liggaam nie in 'n familiegraf begrawe nie (kyk Van Aarde [2001]:138). Na sy dood het Hy egter in die.kerugma opgestaan en Hy het voortgeleef in die verhale waarin sy saak oorvertel is.

Oor die opstanding skryf Van Aarde ([2001]:138) soos volg:

For some in the early church, it was as if they experienced in an altered state of consciousness the appearance of the resurrected Jesus in the form of the Child of Humanity (inter alia Mt 24:30; 27:52-53; 28:16-20) - that triumphant (apocalyptic) figure who had been expected to come at that point in history when the experiences in this world would be almost unendurable so that God's people began to fantasize the inauguration of the kingdom of God transcending experienced time (see inter alia Dn 7:13-14). Others could only hold on to a kerygma of those who said that they had been sent by the exalted Jesus to convey his cause (cf Jn 20:29). One said explicitly that God sent him to become an apostle for the gentiles (see Gl 2:8). It is reported that it happened to him while he was transformed by an experience of an divine performance of light in which the risen Jesus appeared while he only could hear his voice (see Acts 9:3-4; 22:6-7; 26:13-14; cf Gl 1:25-27).

In dié verband verwys Van Aarde ook nog na ander wat volgens Paulus alterbewussynervarings van die opgestane Jesus gehad het, soos byvoorbeeld Maria Magdalena, Petrus, die twaalf, Jakobus en die broer van Jesus. 
Jesus het nie die kerk bedink, gewil, of gestig nie (Van Aarde [2001]:323ev). In dié opsig mag die oorgang vanaf Jesus na die kerk na 'n historiese diskontinuïteit lyk. Tog beredeneer Van Aarde 'n saaklike relasie tussen die Jesus-saak en die teologie van Paulus (kyk hieronder). Die Jesus-beweging en die kerk hoef/kan daarom nie totaal van mekaar losgemaak word nie. Jesus het ook nie sy dood in enige opsig verstaan as 'n kerugma, as 'n evangelie of as 'n goeie tyding nie. Die vroegste gelowiges in Jerusalem het wel die dood van Jesus gesien as 'n gebeure wat deur Homself bewerk is. Hulle het bewys daarvoor gevind in die Ou-Testamentiese geskrifte (Van Aarde [2001]:325). In dié geskrifte het hulle bewyse daarvoor gevind dat Jesus deur God aangeneem is as die Messias van Israel. Vanuit hierdie Messiaanse beskouing oor Jesus en met 'n apokaliptiese inslag ("mind-set"), het hulle waarskynlik begin met ' $n$ institusionalisering van Jesus se laaste maaltyd. Vir hulle was dit ' $n$ tafelgemeenskap wat hulle deelname aan God se spirituele koninkryk gesimboliseer het. Ook 'n dooppraktyk het in hierdie kring ontstaan as ' $n$ "a 'spiritual baptism' in the name of the Father, and the Son and the Spirit of God as sign of initiation into a discipleship of the heavenly kingdom" (Van Aarde [2001]:320). (Kyk egter Schmithals [1994:182-223] wat die mening toegedaan is dat sowel die Nagmaal as die doop eers later in die gemeente van Damaskus ontstaan en ontwikkel het.)

Die vroeë Jerusalemse geloofsgemeenskap het voortgekom uit 'n geloof wat gebaseer is op die opstandingsgeloof. Die ontstaan van dié gemeenskap kan gevolglik nie teruggevoer word na 'n spesifieke gebeure of moment in die lewe van die historiese Jesus nie. Dit was eerder 'n proses van ontwikkeling wat teruggaan op die volgelinge van Jesus wat ervarings van opstandingsverskynings gehad het, te wete Maria Magdalena, Petrus, Jakobus en Paulus. Die eerste geloofsuitsprake oor Jesus kom van volgelinge van Jesus terwyl Hy nog gelewe het, Petrus en Maria Magdalena. Dit kom ook van mense wat Jesus persoonlik geken het, maar nie noodwendig volgelinge van Hom was nie (Jakobus, die broer van Jesus). Verder kom dit ook van mense wat Jesus nie persoonlik geken het nie (Paulus) (Van Aarde [2001]:48). 
- Daar is geen historiese bewys aan te voer dat Jesus verantwoordelik was vir die konsep "die twaalf" of "die apostels" volgens 1 Korintiërs 15:1-7 nie. Hierdie twee konsepte is uitruilbaar gebruik op grond van die invloed van die Jerusalemgemeente wat self daaraan vorm gegee het.

- Hoogs waarskynlik het daar met die dood van Jesus los groepe volgelinge van Jesus bestaan. Na hierdie groepe wil Van Aarde ([2001]:323) verwys as die Jesus-bewegings. Diversiteit is in dié opsig 'n onbetwisbare uitgangspunt van die begin af (Van Aarde [2001]:48). Die diversiteit hou gewoon verband met groepvorming en die soek na identiteit van 'n nuwe groep (kyk Van Aarde [2001]: $328 \mathrm{ev})$.

- Die Jerusalem-gemeente het aanvanklik deel van die tempelkultus gebly. Hulle het na hulleself as "die twaalf" of "die apostels" verwys en nie as die kerk nie. Hulle het 'n apokaliptiese visie op Jesus se werk en die betekenis daarvan vir die gelowiges daarop nagehou. Hierdie kerugma is oorgedra na Paulus en na Markus toe en van hulle af na die ander skrywers van die Nuwe Testament.

- Daarteenoor het Paulus na groepe volgelinge van Jesus as die "kerk" verwys wat los gestaan het van die sinagoge en die tempelkultus. Tussen Paulus en die Jesusbeweging in Jerusalem het die Hellenistiese kerke in Antiogië, Damaskus en Tarsus gestaan (Van Aarde [2001]:326).

- Daar was egter ander groepe Jesus-volgelinge, byvoorbeeld dié groepe aan wie die Spreuke Evangelie Q en die Evangelie van Tomas geskryf is. Hulle het Jesus suiwer as 'n etiese model voorgehou en gevolg. Hulle het nie die apokaliptiese kerugma van Jesus as die sterwende en opgestane in hulle Jesu-ologie opgeneem nie en ook nie die betekenis van kruis en opstanding bedink, geglo of verkondig nie. Van hierdie groepe ( $\mathrm{vgl}$ die Ebioniete as 'n na-70 $\mathrm{nC}$ voortsetting hiervan) was baie sterk partikulier ingestel. Hierdie Jesus-volgelinge, en ook ander asketiese (later dosetiese), nie-kerugmatiese groeperings is later deur die kerklike konsillies gekonfronteer met die vraag na die kanon en die ontologiese dogma van die twee-nature van Jesus (Van Aarde [2001]:331).

- $\quad$ Alhoewel die vroeë Christendom as 'n faksie binne Israel beskou moet word, het die Christelike beweging met verloop van tyd 'n duidelike aparte groep los van 
die sinagoge begin vorm aanneem. Spesifieke sake, soos die opstandingsgeloof, die geloof in die wonderbaarlike verwekking van Jesus, en die nie-fisiese verstaan van die konsep "kinders van Abraham", het die Christendom teenoor (opposing) die sinagoge te staan gebring. Dit bly egter 'n ope vraag of die kerk 'n kontinuïteit of 'n diskontinuïteit met die Jesus-saak reflekteer (Van Aarde [2001]:320). Die onderskeidende kwaliteit van die Jesus-saak is die inklusiwiteit en die antihiërargiese tendens daarvan. Die Jerusalemse gemeente het byvoorbeeld nie dieselfde openheid vir die heidene en ander gemarginaliseerdes gehad nie. Hulle het wel die Ou-Testamentiese geskrifte bestudeer en bevind dat Jesus deur God as die Messias van Israel aangeneem is. Spoedig egter het die beweging ook wyer gegaan as net die Jerusalem-gemeente met hulle inperking tot Israel. Hierin het veral die interpretasie van Paulus 'n oorheersende rol in die Christelike tradisie oor Jesus gespeel. Hierdie interpretasie was egter net 'n deel van die "entire tradition of Christian witness". Dit het tot gevolg gehad dat slegs 'n gedeelte van die getuienis van geloof van die vroeë Christendom in die Nuwe Testament opgeneem is (Van Aarde [2001]:48). Sedert die tyd van Konstantyn die Grote in die vierde eeu het daar met die hulp van gekompliseerde Grieks-filosofiese metafisika en Romeinse regsterminologie (kyk Van Wyk 1997:727-729) 'n beeld van Jesus ontwikkel wat bekend staan as die klassieke ontologiese Christologie.

\subsection{Kontinuïteit en diskontinuïteit}

Van Aarde begrond die saak van kontinuïteit-diskontinuïteit sterk histories en teologies (saaklik) in terme van die Jesus-saak en die kern van Paulus se teologie. Paulus het 'n teologiese konstruk ontwikkel van deelname in die opgestane Christus Jesus. Hierdie eenheid met die Jesus-saak is 'n geloofservaring wat beskryf kan word as 'n alter-staat van bewussyn as gevolg van die spirituele aard daarvan. Hierdie spiritualiteit word deur Paulus beskryf met die formule om "in Christus te wees" (kyk Van Aarde [2001]:321). Deur die voortdurende ervaring van die betekenis van Jesus se lewe deur die opstandingsgeloof het Paulus dáárin van die Jerusalem-gemeente verskil deurdat hy verkondig het dat Israel ook (saam met Christus) gesterf het (vgl Rom 6). Vir Paulus het dit beteken dat die 
"Israel van God" geheel getransformeer is na 'n geestelike entiteit. Dit beteken dat die kerk, as so 'n "alter-Israel", beskou is as 'n beweging van mense wat glo in Christus en in die Kurios - die Jesus van geloof vir beide Israeliete en nie-Israeliete. Alhoewel die historiese Jesus nie voorsien het dat 'n entiteit soos die kerk gebou sal word op só 'n interpretasie van sy dood nie, was Paulus se alter-visie van egalitarisme en kulturele subversiwiteit in kontinuiteit met Jesus se alter-verhouding met God as die Vader van "nobodies".

According to the core of the Pauline and gospel tradition in the New Testament, Jesus' interpretation of the kingdom of God, his wisdom, his redefinition of the concept "children of Abraham" ("children of God") constituted the essence of human self-understanding.

(Van Aarde [2001]:321)

Die essensie van die godsdiens is vir Paulus om te doen wat inpas by God (Rom 12:1-2). Indien verwerping en dood gesien moet word as mislukking, dwaasheid (folly) of belediging (offense), dan sou die visie van Jesus as 'n mislukking gesien moes word. Maar hierdie paradoksale persepsie is wat die lewe van Jesus was. Die Pauliniese tradisie sit hierdie visie voort en wel binne 'n kontra-kulturele perspektief, sonder om te ontvlug van realiteite of om te vlug in 'n fantasiewêreld (Van Aarde [2001]:322). Dit versterk die visie dat krag moontlik is in swakheid, wysheid in dwaasheid, eer in skande en lewe in dood. Aangesien God skande in eer omkeer, is die opstandingsgeloof volgens Paulus die teken van 'n nuwe geboorte, 'n nuwe skepping ( 2 Kor 5:17; Gal 6:15) die geboorte van die "ware Israel", die "Israel van God" (Gal 6:16). "According to Jesus' gospel, an 'altered' vision, not arrogant egotism, constitutes the self-understanding of human beings" (Van Aarde [2001]:322).

Om die fondament van die kerk in die Jesus-saak te ontken, is om die historiese wieg van die kerk te ontken. Dit veroorsaak dat die essensie van die kerk verdamp (evaporate) in 'n ekklesiologiese ideologie. Daarom moet die kern van die Pauliniese evangelie met betrekking tot die gekruisigde Jesus (1 Kor 1:17-31) verstaan word as gekondenseerde geskiedenis van die historiese Jesus (Van Aarde [2001]:322). 
Anders as ander historiese Jesus-navorsers (kyk Funk 1996:314) is Van Aarde dus nie van mening dat die tyd vir die kerk uitgedien is nie. Deur die geskiedenis heen is die kerk deur talle "ander" sake as die Jesus-saak beproef. In die postmoderne wêreld word die kerk en die Christendom deur institusionalisme en sekularisasie bedreig. Met dié bedreiging op hande, behoort die kerk die Jesus-saak opnuut verder te laat gaan (Van Aarde [2001]:332).

\subsection{Die rol van die belydenis en die kanon}

Van Aarde handel eksplisiet oor sy binding aan die kerklike belydenis en leer. Hy wil as deel van sy ondersoek na die historiese Jesus die dogma dekonstrueer en met behulp van 'n wetenskapsteoretiese betrokke hermeneutiek die Jesus-saak by die mens van vandag tuisbring.

Dit beteken egter nie dat my program om die dogma te dekonstrueer 'n keuse vir relatiwisme is wat oordeel dat enigiets aanvaarbaar is nie. Ek gebruik die woord "dekonstueer"...met die klem nie op "afbrekende vernietiging" nie, maar op "analitiese konstruksie". Die program wat ek binne die raamwerk van my historiese Jesus-navorsing as "betrokke hermeneutiek" beskryf het..., veronderstel nie ' $n$ gesindheid van om absoluut vry van kerklike konfessies te wees nie. So ' $n$ vrysinnigheid is die kenmerk van die liberale teologie. Vir my is betrokke hermeneutiek van Christelike dokumente kritiese teologie wat geloof ernstig opneem. Wat geloofsdokumente van die kerk betref, respekteer ek met hierdie hermeneutiese program die konfessionele formules in terme van hulle bedoeling. Betrokke hermeneutiek is vir my die kritiese ondersoek na wat fundamenteel ten grondslag van die artikulasie van geloof kon lê. Omdat ek nie meen dat daar so iets soos die waarheid is nie, of dat "waarheid" eens-en-vir-altyd in formules vasgeskryf kan word nie, bestaan hierdie ondersoek vir my uit 'n oneindige soeke - 'n reis wat nie eindig nie.

(Van Aarde 1999:457-458)

Wanneer hy handel oor verskillende weë waardeur mense God ontmoet, merk hy soos volg op: "I would like to emphasize that, to me, Jesus Christ is not only $a$ but the 
manifestation of God" (Van Aarde [2001]:16). In dié verband verwys hy na "Jesus as God" [waarskynlik eerder as na Jesus is God], maar dan nie noodwendig in die ontologiese sin van die woord nie (Van Aarde [2001]:45).

In sy soeke na en die formulering van die Jesus-saak het Van Aarde ([2001]:45) saam met Funk (1996:11) tot die slotsom gekom dat hy nie langer sy geloof kan laat berus op die geloofsoortuiging van ander (d i Petrus en Paulus - Van Wyk) nie, maar op die Jesus-saak as sodanig. In dié verband beklemtoon hy dat die Christendom nie 'n godsdiens is wat gebaseer is op 'n boek nie, maar op die historiese persoon, Jesus van Nasaret. Hierdie standpunte het verreikende implikasies vir die hantering van die belydenis en die vraag na die kanon.

Die bestudering van die geskrifte van die vroeë Christendom met 'n sterk historiese bewussyn het hom sensitief gemaak vir die bestaan van trajekte van geloofsoortuigings binne die vroeë Christendom. 'n Sterk historiese bewussyn het by hom die oortuiging gevestig dat geloofstradisies (nie alleen dié wat lank deur die kerk as "waarheid" voorgehou is om daarvolgens te leef nie) nie noodwendig korrespondeer met Bybelse idees nie. Maar die saak gaan nog verder. Daar is selfs sommige van daardie Bybelse idees wat trajekte tot gevolg gehad het wat die Jesus-saak nie verdiep het nie, maar vervreem het (Van Aarde [2001]:51).

Van Aarde se siening van die Christendom wat grond in die Jesus-saak, beïnvloed dus sowel sy opinie oor die kerklike belydenis as sy kanonbeskouing. Ten opsigte van die belydenis en die dekonstruksie daarvan, onderskei hy vier fases van belydenisvorming wat $\mathrm{Hy}$ aan die hand van die twee nature-leer oor Jesus demonstreer (kyk Van Aarde 1999). Die eerste fase is om 'n fundamentele religieuse ervaring te verbaliseer. Dit het in die lewe van Jesus vergestalt toe Jesus God "Vader" genoem het op grond van die individuele religieuse ervaring van God se onbegrensde en direkte teenwoordigheid in sy eie (en ander) se lewens. Fase twee is metaforiese taalgebruik waardeur ander op grond van die aanvanklike religieuse ervaring gelei word tot soortgelyke religieuse ervarings. In terme van belydenisvorming binne die vroeë kerk het dit gebeur toe die Jesussaak uitgekring het en die metafoor "seun (= kind) van God" deel geword het van Christene se taalgebruik. Ander gelowiges is ook kinders van God genoem. Christene ervaar God se teenwoordigheid op grond van hulle "deelhê aan" Jesus, Seun van God 
(Van Aarde [2001]:462]. Hierdie metafoor waarin Jesus as die "Seun van God" beskryf word, is in die Nuwe Testament uit en uit funksioneel en nie ontologies nie. Paulus en Johannes beskryf die "twee nature" wat sulke kinders van God het in terme van 'n "vleeslike geboorte" (as mens) en 'n "geestelike geboorte" (vanweë God). Fase drie is wanneer die gemeenskaplike metafoor in konfessionele formules vasgelê word. Dit kan gesien word in die gebruik van die uitdrukking "Seun van God" as 'n "konfessionele waarde-oordeel" (Würdeprädikation), dit wil sê as 'n "Christologiese titel". Ná die Nuwe Testament het Jesus se "Seun van God"-skap in 'n dogma ontwikkel. 'n Funksionele metafoor het 'n ontologiese metafoor geword. Funksionele Christologie het ontologiese Christologie geword. Die konsep "twee nature" het dus aanvanklik as 'n metaforiese taalgebruik ontstaan. Dit was uitdrukking van die fundamentele ervaring dat niks wat fisies of kultureel van aard was, God se geestelike en onbemiddelende teenwoordigheid kon verhinder nie. 'n Mensekind is "weergebore" as kind van God. Hierdie twee naturemetafoor het ontwikkel in ' $n$ konfessionele formule (wat in Fase 4 by Nicea in Neoplatoniese synsfilosofiese en regsterminologiese begrippe dogmaties vasgelê is). Dit beteken daar het afstand gekom tussen die oorspronklike konteks en die latere konteks waarin die formule vasgelê is. So het dit in 'n onbevraagtekende, vaste dogma van Jesus se "twee nature" gestalte gevind. In die periode van die Protestantse skolastiek ná Fase 4 vind daar vervreemding plaas wanneer die dogma nie meer die bedoeling van die oorspronklike verbaliseer nie (Van Aarde [2001]:464). Die Niceense Geloofsbelydenis wat ontologies gehandel het oor die twee nature van Jesus, het die bedoeling gehad om die menslikheid van Jesus te beklemtoon. Die dogma wat binne die sestiende- en sewentiende-eeuse Rooms-Katolieke en Protestantse tradisies ontwikkel het, het dié tendens voortgesit. Ortodokse fundamentalisme [Van Aarde beskryf nêrens wie of wat hierdie Gereformeerde, ortodokse fundamentalisme is nie - Van Wyk] het egter die rigting omgekeer en begin om die Godheid van Jesus te beklemtoon. Sodoende het vervreemding van die oorspronklike geloofservaring ontstaan. Dogma kan (en het) teen dié agtergrond in die hand van magsbelange gespeel. Die dogma behoort dus gedekonstrueer te word om die vervreemding uit te skakel en te vra of die metafore waarin die oorspronklike religieuse ervaring verwoord is, steeds funksioneel vir die gelowige vandag is. Uiteindelik betoog Van Aarde dat die metafoor "kind van God" steeds funksioneel en relevant is om 'n 
fundamentele geloofservaring van God se teenwoordigheid uit te druk (Van Aarde [2001]:465-466).

Van Aarde se siening van die Jesus-saak beïnvloed ook sy kanonbeskouing. As gevolg van die feit dat daar so 'n magdom van probleme ten opsigte van teksoorlewering is, en vanweë die feit dat daar vandag invloedryke historici en eksegete is wat betoog dat sommige van die geskrifte wat nie in die kanon opgeneem is nie, outentieke Jesuswoorde bevat of ten minste op trajekte dui wat verder teruggaan as die Nuwe-Testamentiese evangeliemateriaal, behoort tekshistoriese én historiese Jesus-navorsing nie beperk te word tot die manuskripte van die Nuwe Testament nie (Van Aarde [2001]:23-24).

'n Noukeurige lees van alle relevante tekste dui daąrop dat uitsprake van Jesus die geloofsoortuiging van na-Pase Christene reflekteer. Dit kom onder andere na vore in apologetiese tendense by Jesus wat 'n refleksie van apologie teenoor na-Pase opponente van die Christelike gemeenskap verteenwoordig. Die ondersoek na onder andere die Evangelies van Tomas en Petrus help om die historiese Jesus te onderskei van die beelde wat die kanonieke evangelies van Jesus teken (Van Aarde [2001]:29). Om by die "werklike" boodskap van Jesus uit te kom, is daar geen ander manier as om die pad te volg deur die literêre getuienis van gelowiges wat self begin verkondig het dat Jesus die Messias is, die Kind van die Mens (Child of Humanity) is, die Here is, die Kind van God is, God is nie (Van Aarde [2001]:33).

Wetende dat hierdie benadering tot die kanon en buite-kanonieke tekste reperkussies in sy eie kerk kan veroorsaak, stem Van Aarde ([2001]:24) met Willi Marxsen saam dat die Nuwe-Testamentiese kanon self nie die primêre en formeel prinsipiële Christelike getuienis van God se komende gebeure (heil) is nie. Op voetspoor van Martin Luther (sy Was Christum treibet-beginsel) beskou Van Aarde die Jesus-saak as die kanon agter die kanon. Trouens, wat Luther bedoel het met Was Christum treibet as kriterium vir die kanon, is dieselfde wat Van Aarde ([2001]:53) verstaan as die Jesus-saak. "For Christians it is the very first aspect of what the authority of the Scriptures ought to be. This foundation is the Jesus event, in other words the cause of Jesus which preceeds the kerygma of the church, although it goes dialectically together with the kerygma" (Van Aarde [2001]:53). 
Die Jesus-saak moet dus beskou word as die kanon agter die kanon. Dít is terselfdertyd ook die wieg van die kerk. Wat gesagsvol vir die Christen is, is nie die gegewenheid van 'n sogenaamde "foutlose" Bybel, of 'n "foutlose" kerk of 'n inherente rasionaliteit van die menslike verstand nie. Die "gesag" van die Skriftuurlike getuienis lê daarin dat dit gelowiges uitnooi om hulle woorde en dade te laat ooreenstem met die Jesus-saak. Al lesende en/of luisterende gaan die gelowige op weg - soos die Ethiopiër van ouds - 'n reis wat 'n soeke veronderstel. Die soektog na dit wat fundamenteel in die geloof is, is derhalwe nie 'n soektog na tradisies en die ontwikkeling daarvan nie; dit gaan nie om die vind van die historiese Jesus nie, maar die soektog na die Jesus-saak. Die feit dat die tekste 'n appèl op die leser maak om aan te hou soek na die Jesus-saak, gee aan die tekste gesag (Van Aarde [2001]:56)

Alhoewel dit nie sy oogmerk is om die Christelike kanon te destabiliseer nie, of om dit met ' $n$ ander kanon te probeer vervang nie, verwelkom hy die debat oor die besinning van die worstels van die Christendom en die implikasies daarvan vir die kanonbeskouing van die kerk. Die Nuwe Testament verteenwoordig immers maar enkele perspektiewe op die totaal van getuienisse oor Jesus en is dus lank nie omvattend ten opsigte van die Jesus-saak nie (Van Aarde [2001]:55). Hy verwelkom die moontlikheid van 'n "scholars canon" wat sal bestaan uit al die geskrifte van die eerste twee eeue wat konsistent en lojaal fokus op die Jesus-saak (Van Aarde [2001]:49). So 'n kanon langs die huidige kanon kan Christene help om die oorsprong van hulle geloof beter te begryp.

\subsection{Teologiese agenda}

Anders as die Jesus Seminar wat as sodanig nie interesse in die teologiese relevansie van hulle historiese navorsing het nie, wil Van Aarde ([2001]:35) bewustelik oor teologiese kwessies reflekteer. Uit die boek as geheel spreek die indruk van nie net die saak van die historiese Jesus wat hanteer word nie, maar ook die vraag na geloof, na God en die verhouding tussen God en mens. Daar is veral twee teologiese redes waarom Van Aarde ([2001]:10-11) meen die vraag na die historiese Jesus nie ontduik kan word nie.

Eerstens is daar onder navorsers die groeiende bewussyn dat wanneer jy die vraag na die historiese Jesus by die voordeur weier, die twyfel oor die vraag na God by die agterdeur inkom (Van Aarde [2001]:73). Binne dié konteks word die moeilike vraag oor 
geloof in Jesus as die Christus hanteer (Van Aarde [2001]:39ev). Daar kan nie sprake wees van geloof in die historiese Jesus nie. God word bekend deur God se eie inisiatief van selfbekendmaking deur die medium van die geskiedenis.

\begin{abstract}
By this I mean that, for Christian believers, God is manifested in the human Jesus of Nazareth...[A]lthough God's becoming event in Jesus of Nazareth occured historically, and is therefore in principle open to historical investigation, the act of faith that confesses that Jesus is the Christ, the Lord, the Child of God, God self, is not grounded in historiography as such: "no one can say that 'Jesus is the Lord' but by the Holy Spirit" (1 Cor 12:3). But "(i)f God has made this human being - and not just any other human being - to be the Christ, as faith confesses, the faith must be interested to know what can be known about this person: but not in order to ground faith in Jesus Christ historically, but rather to guard it from docetic selfmisunderstanding".
\end{abstract}

(Van Aarde [2001]:41; aanhalings is uitsprake van Jüngel).

Die materiële verband tussen die historiese Jesus en die Christus van die geloof (veral soos deur Paulus geformuleer) moet gesoek word in die Jesus-saak. Hierdie materiële verband kan onder andere gesien word in Jesus se prediking oor die koninkryk van God en Paulus se verstaan van die gelowige se lewe "in Christus". Deur en in Christus het elke mens direkte en onbemiddelende toegang tot God (kyk Van Aarde [2001:45).

Tweedens werk navorsers vandag binne 'n veel wyer verwysingsraamwerk as vroeër. Die historiese metode en die gebruikmaking van die sosiale wetenskappe laat navorsers toe om histories baie verder te vorder as in die verlede. Hedendaagse historiese Jesus-navorsing word trouens gekenmerk deur die multidissiplinêre aard daarvan (Van Aarde [2001]:32, 79, 84). So is die multidissiplinêre aspekte tipies van Van Aarde ([2001]:35) se historiese navorsing.

Volgens Van Aarde ([2001]:12) moet die vraag na die historiese Jesus as betrokke hermeneutiek (engaged hermeneutics) voortgang vind op grond van die kultuur-kritiese waarde daarvan. Vandag is daar in die "global village" miljoene kinders wat vaderloos 
opgroei. Die vaderloosheid van Jesus en die metafoor van God as Vader kan vir hierdie kinders van ryke singewende betekenis wees.

My book is about the historical Jesus who filled the emptiness caused by his fatherlessness by his trust in God as his father. Among the earliest faith assertions of Christians which gave them authentic existence was their believe in Jesus as child of God. Searching for Jesus as child of God could also restore authenticity in the lives of many people today.

(Van Aarde [2001]:13)

Dat Jesus as 'n vaderlose kind opgegroei het, behoort verder in berekening gebring te word wanneer gepoog word om die optrede van Jesus te verduidelik soos dit opgeteken is in die dokumente van die vroegste Christendom (Van Aarde [2001]:14). Van Aarde se hele boek het ongetwyfeld 'n duidelike nie-seksistiese inslag. Dit spreek vanself uit die titel en die res van die boek waar daar nie van Jesus gepraat word as "Seun van God" en "Seun van die Mens" nie, maar as "kind van God" en "Kind van die Mens" (Child of Humanity - Van Aarde [2001]:33).

\section{SAMEVATTING}

Wanneer die verskeidenheid van profiele en konstrukte wat in resente Jesus-navorsing na vore kom, in die oog gehou word, val dit op dat die konstrukte van Crossan en Van Aarde in verskeie opsigte as "versoenend" getipeer sou kon word. Dit geld die ooreenkomste met betrekking tot die spesifieke profiele wat van Jesus geteken word (sy perspektief op die radikale gelykheid van alle mense, sy behorenheid tot en ingebedheid in die kleinboerderygemeenskap van Galilea, sy anti-hiërargiese houding as kultuurkritiek op die samelewing van die dag). Beide Crossan en Van Aarde hanteer die vraag na kontinuiteit en diskontinuïteit binne die hermeneutiese vertrekpunt van die dialektiek. Hierdie hermeneutiese benadering slaan vir albei die brug om steeds, ten spyte van kontroversiële resultate waartoe hulle historiese navorsing hulle bring, hulle tuis te voel binne die dampkring van kerk, teologie en belydenis (sonder dat hulle in hulle historiese navorsing 
daardeur ingeperk of geïnhibeer word). Dit beteken dat beide se navorsing vir kerk en teologie tot verdere teologiese besinning diensbaar is.

Die feit dat die historiese konstrukte van Crossan en Van Aarde in verskeie opsigte as versoenbaar getipeer kan word, beteken nie dat enigeen van hulle hulle onafhanklikheid prysgegee het nie. Daarvoor spreek die onafhanklikheid en erns waarmee elkeen die historiese ondersoek benader, te duidelik. Die historiese metode van onafhanklike, meervoudige betuiging is vir albei van direkte en wesenlike belang. Dit blyk verder ook in die onafhanklike resultate wat steeds deur elkeen op die tafel geplaas word (kyk byvoorbeeld Crossan se insigte rondom die lydensgeskiedenis van Jesus asook sy teologiegeskiedenis aan die een kant en Van Aarde se insigte rondom die lewe van Jesus vóór Johannes die Doper, sy profiel van 'n vaderlose Jesus en dies meer).

Die onafhanklike, dog grootliks versoenende historiese konklusies waartoe Crossan en Van Aarde kom, open belangrike perspektiewe vir die "betroubaarheid" van historiese navorsing en die bydrae wat dit tot die teologiese debat kan lewer.

\section{Literatuurverwysings}

Funk, R W 1996. Honest to Jesus: Jesus for a new millenium. San Francisco: Harper.

Funk, R W \& Hoover R W (eds) 1993. The five Gospels: The search for the authentic words of Jesus. New York: Macmillan.

Van Aarde, A G 1999. Dekonstruksie van dogma: 'n Eietydse ondersoek na die spore van die leer van die twee nature van Jesus. HTS 55, 437-470.

- [2001]. Fatherless in Galilee: Jesus child of God. Harissburg, PA: Trinity Press International.

Van Wyk, D J C (jr) 1997. Die belydenis "Jesus is God" in die vroegste Christendomme: 'n Ondersoek na metodes en kriteria. HTS 53, 722-750. 